\title{
EFEKTIVITAS PENGARUH BESARAN BIAYA PROMOSI DALAM PENGHIMPUNAN DANA PIHAK KETIGA
}

\author{
Puji Lestari \\ Fakultas Syariah dan Hukum UIN Syarif Hidayatullah Jakarta \\ Jl. Ir. H. Juanda 95 Ciputat Jakarta \\ Email:Puji_ls@yahoo.com
}

\begin{abstract}
Abstrak: Promosi merupakan salah satu variabel dalam bauran pemasaran yang sangat penting dilaksanakan oleh perusahan dalam memasarkan produk jasa. Kegiatan promosi bukan saja berfungsi sebagai alat komunikasi antara perusahaan dengan konsumen, melainkan juga sebagai alat untuk mempengaruhi konsumen dalam kegiatan pembelian atau penggunaan jasa sesuai dengan keinginan dan kebutuhannya. Hal ini dilakukan dengan menggunakan alat-alat promosi.
\end{abstract}

Kata Kunci: Promosi, Pihak Ketiga, Dana

\section{Pendahuluan}

Berbeda dengan negara-negara maju, negara-negara berkembang, seperti Indonesia, pemahaman tentang bank di negara ini belum utuh. ${ }^{1}$ Sebagian masyarakat hanya memahami bank hanya sebatas tempat menyimpan dan meminjam uang belaka. Bahkan terkadang sebagian masyarakat sama sekali belum memahami fungsi bank seutuhnya, sehingga tidak heran jika pandangan mereka tentang bank sering diartikan secara keliru. Selebihnya banyak masyarakat yang tidak paham sama sekali tentang dunia perbankan. Semua ini tentu dapat dipahami karena pengenalan dunia perbankan secara utuh terhadap masyarakat belum optimal, terutama melalui ilmu pemasaran bank.

Market share bank syari'ah di Indonesia saat ini, relatif masih kecil,

${ }^{1}$ Kasmir, Pemasaran Bank (Jakarta: Kencana, 2005), Cet. Kedua, h. 7-8. 
belum mencapai $2 \%$ dari total asset bank secara nasional. Menurut Siti Fajriyah $^{2}$, salah seorang Deputi Gubernur Bank Indonesia, jumlah nasabah Bank syari'ah saat ini, baru sekitar 3 juta orang. Padahal jumlah umat Islam potensial untuk menjadi konsumen bank syariah lebih dari 100 juta orang. Dengan demikian, mayoritas umat Islam belum berhubungan dengan bank syari'ah. Banyak faktor yang menyebabkan mengapa umat Islam belum berhubungan dengan bank- syariah, antara lain: tingkat pemahaman dan pengetahuan umat tentang bank syariah masih sangat rendah, Masih banyak yang belum mengerti dan salah memahami tentang bank syariah dan menggangapnya sama saja dengan bank konvensional. Bahkan sebagian ustadz yang tidak memiliki ilmu yang memadai tentang ekonomi Islam (ilmu ekonomi makro, moneter dan teknis perbankan) masih berpandangan miring tentang bank syariah, karena kurang informasi keilmuan tentang bank syariah. Selain itu, belum ada gerakan bersama dalam skala besar untuk mempromosikan bank syariah dan terbatasnya pakar dan SDM ekonomi syari'ah. Serta peran pemerintah masih kecil dalam mendukung dan mengembangkan ekonomi syariah.

Satu dari sepuluh pilar pengembangan bank syari'ah yakni dalam hal sosialisasi adalah sinergi ${ }^{3}$, Sinergi sesama bank syari'ah merupakan sebuah keniscayaan yang tak terbantahkan untuk mengembangkan dan mempromosikan bank syari'ah secara signifikan. Bank-bank syari'ah tak boleh promosi dan bekerja secara sendiri-sendiri. Kegiatan Indonesia syari'ah Expo yang baru-baru ini dilaksanakan merupakan bentuk sinergi yang perlu diteruskan.

Masih banyak bentuk sinergi lain yang bisa dilakukan, seperti menggelar kegiatan bersama dalam promosi di tv, radio, menggelar workshop dan training ulama dan dosen ekonomi, penerbitan majalah dan buletin dan sebagainya.

Fakta membuktikan bahwa biaya untuk mengembangkan bank syari'ah oleh Bank Indonesia masih sangat kecil, sehingga dalam berbagai

${ }^{2}$ Siti Fajriah, "10 Pilar Pengembangan Bank Syari'ah", artikel diakses pada 11 Januari 2008 dari http://kasei-unri.org/index.php?option=com.

${ }^{3}$ Ibid., 
momentum promosi bank syari'ah, sumbangan Bank Indonesia masih sangat kecil. Berdasarkan data dari BI, biaya promosi dan belanja iklan industri perbankan syari'ah selama 2007 sebesar Rp.91,3 miliar. ${ }^{4}$ Biaya tersebut baru 1,9\% dari biaya promosi bank konvensional.

Kecilnya market share sebagian besar disebabkan karena sedikitnya alokasi dana untuk pengembangan bank syari'ah dari Bank Indonesia. Dibutuhkannya dana untuk edukasi dan pencerdasan masyarakat tentang bank syari'ah. Promosi, pendidikan dan pelatihan membutuhkan biaya yang tidak sedikit.

Saat ini, eksistensi perbankan syariah tergolong masih belia. Umurnya masih belasan tahun. Jika ada orang yang membandingkan dengan umur bank konvensional, perbandingan semacam ini tidaklah seimbang. Karena, dari sisi umur, bank konvensional sudah lama dikenal oleh masyarakat Indonesia. Wajar jika masyarakat lebih terbiasa bertransaksi dengan bank konvensional. Sedangkan dalam prospek bank syari'ah tidak bisa dibantah, bahwa perbankan syari'ah mempunyai potensi dan prospek yang sangat bagus untuk dikembangkan di Indonesia. ${ }^{5}$

Prospek yang baik ini setidaknya ditandai oleh empat hal ; Pertama, Jumlah penduduk Indonesia yang mayoritas beragama Islam merupakan pasar potensial bagi perkembangan bank syari'ah di Indonesia. Kedua, perkembangan lembaga pendidikan Tinggi yang mengajarkan ekonomi syari'ah semakin pesat, baik S1, S2, S3 juga D3. Dalam lima tahun ke depan akan lahir sarjana-sarjana ekonomi Islam yang memiliki paradigma, pengetahuan dan wawasan ekonomi syari'ah yang komprehensif.

Ketiga, Fatwa MUI tentang keharaman bunga bank, bagaimanapun akan tetap berpengaruh terhadap pertumbuhan perbankan syari'ah. Pasca fatwa MUI tersebut, terjadi shifting dana masyarakat dari bank konvensional ke bank syari'ah secara signifikan yang meningkat dari bulan-bulan sebelumnya. Menurut data BI, dalam waktu satu bulan pasca fatwa MUI,

4 “ Biaya Promosi dan Iklan Perbankan Syariah", diakses pada tanggal 11 Januari 2008 dari situs http://www.Bisnisonline.co.id

${ }^{5}$ i akses pada tanggal 5 Januari 2008 dari situs http//:www.Bisnis Indonesia.com 
dana pihak ketiga yang masuk ke perbankan syari'ah hampir 1 triliyun. ${ }^{6}$

Keempat, harapan kepada sikap pemerintah cukup besar untuk berpihak pada kebenaran, keadilan dan kemakmuran rakyat. Political will pemerintah untuk mendukung pengembangan perbankan syari'ah di Indonesia tinggal menunggu waktu, yakni dengan melihat keunggulan bank syari'ah.

Banyak peran Bank Indonesia dalam mendorong pertumbuhan bank syari'ah, khususnya dalam regulasi. Namun kegiatan sosialisasi dan pencerdasan bangsa masih relatif kecil. Tetapi, dalam strategi kebijakan pengembangan perbankan syariah di indonesia saat ini sudah ada langkah nyata yang dilakukan BI untuk mempercepat dan menyosialisasikan Bank Syariah kepada masyarakat adalah dengan diluncurkannya logi iB (Islamic Banking) pada 2 Juli 2007.7 Serta 6 pilar program akselerasi pengembangan perbankan syariah antara lain: Penguatan Kelembagaan Bank Syariah, Pengembangan Produk Bank Syariah, Intensifikasi Edukasi Publik dan Aliansi Mitra Strategis, Peningkatan Peranan pemerintah dan Penguatan Kerangka Hukum Bank Syariah, Penguatan SDM Bank Syariah, dan Penguatan Pengawasan Bank Syariah.

Setiap perusahaan selalu berusaha untuk dapat tetap hidup, berkembang, dan mampu bersaing. Dalam rangka inilah, maka setiap perusahaan selalu menetapkan dan menerapkan strategi dan cara pelaksanaan kegiatan pemasarannya. Kegiatan pemasaran yang dilakukan, diarahkan untuk dapat mencapai sasaran perusahaan yang dapat berupa tingkat laba yang diperoleh perusahaan dalam jangka panjang dan share pasar tertentu serta total unit dan total volume penjualan tertentu dalam suatu jangka tertentu. ${ }^{8}$ Terbukti pertumbuhan jumlah bank syari'ah di negeri ini mencapai 13 persen. Menurut data dari Bank Indonesia, hingga Mei 2007

${ }^{6}$ Ibid,

7 Ani Murdiati "Perkembangan dan Kebijakan Pengembangan Bank Syariah di Indonesia”, dalam Training Perbankan Syariah kerjasama PT. Bank Syariah Mega Indonesia dengan BEM Fakultas Syariah dan Hukum NR, 11-12 Juni 2008, Jakarta, UIN Syarif Hidayatullah, 2008, h.3.

${ }^{8}$ Sofjan Assauri, Manajemen Pemasaran, (Jakarta: PT.Raja Grafindo Persada, 2004), Cet.Keempat, h. 197. 
lalu jumlah bank syari'ah tercatat sebanyak 26 buah yang terdiri dari tiga Bank Umum Syari'ah (BUS) yang salah satunya adalah Bank Syari'ah Mega Indonesia dan 23 Unit Usaha Syari'ah (UUS). ${ }^{9}$

Promosi merupakan salah satu variabel dalam bauran pemasaran yang sangat penting dilaksanakan oleh perusahan dalam memasarkan produk jasa. Kegiatan promosi bukan saja berfungsi sebagai alat komunikasi antara perusahaan dengan konsumen, melainkan juga sebagai alat untuk mempengaruhi konsumen dalam kegiatan pembelian atau penggunaan jasa sesuai dengan keinginan dan kebutuhannya. Hal ini dilakukan dengan menggunakan alat-alat promosi. ${ }^{10}$

Promosimemangmerupakanalatyang digunakanuntukmeningkatkan angka, dalam hal ini penjualan. ${ }^{11}$ Sementara, sosialisasi adalah suatu hal yang bersifat memberikan pemahaman kepada masyarakat akan hal yang baru. Strategi promosi dan anggaran Bank Syariah Mega Indonesia setiap tahunnya disepakati dalam rapat anggaran. Aktifitas promosi Bank Syariah Mega Indonesia telah memberikan kontribusi yang sangat signifikan.

Strategi yang saat ini dilakukan dalam hal promosi salah satunya adalah dimana saat ini BSMI berupaya meningkatkan dana murah yang dijaring dari tabungan dan giro. ${ }^{12}$ Bank Syariah Mega Indonesia (BSMI) melakukan kerja sama pembukaan layanan syariah di lima kantor cabang Bank Mega. Kelima kantor cabang berada di wilayah DKI Jakarta. Pembukaan tersebut bertujuan untuk mendorong penghimpunan dana pihak ketiga (DPK) retail dan murah. Dengan demikian, komposisi dana murah pada DPK BSMI dapat ditingkatkan. Rencananya, BSMI akan menamakan kantor channelling tersebut dengan sebutan galeri syariah. Mengenai DPK, BSMI tengah berupaya meningkatkan dana retail karena dana tersebut merupakan dana murah. Dana retail dimaksud adalah DPK

${ }^{9}$ Faizi, "Bank Syariah Entaskan Kemiskinan", artikel di akses pada tanggal 11 Januari 2008 dari situs http://www.republikaonline.co.id

${ }^{10}$ Rambat Lupiyoadi, Manajemen Pemasaran Jasa: Teori dan Praktik, (Jakarta: PT. Salemba Emban Patria, 2001), h. 108.

${ }^{11}$ Beny Wicaksono, "Pemilihan Media Dalam Strategi Promosi Yang Optimal Untuk Meningkatkan Volume Penjualan", artikel diakses pada 2 Februari 2008 dari www. republikaonline.co.id

12 Ibid., 
yang dijaring dari produk tabungan dan giro. Rencana peningkatan dana murah tersebut bertujuan untuk menurunkan biaya dana (cost of fund). Hal tersebut agar biaya dana dapat dapat ditekan sehingga tidak memukul sisi rentabilitas atau kemampuan memperoleh laba BSMI.

Penyediaan biaya promosi dapat dihubungkan dengan pendapatan penjualan perusahaan. Ada anggapan bahwa biaya promosi harus mempunyai hubungan yang erat dengan pergerakan penjualan perusahaan selama siklus bisnis itu berjalan. ${ }^{13}$ Dapat dikatakan pula bahwa dalam teorinya apabila biaya promosi besar atau dinaikan dari sebelumnya maka penjualan dalam hal ini adalah dana pihak ketiga pun ikut mengalami kenaikan, tetapi dalam faktanya di Bank Mega Syariah dalam beberapa periode yang diteliti bahwasanya kenaikan dana pihak ketiga tidak diimbangi dengan besarnya biaya promosi yang dikeluarkan, artinya ketika Bank Mega Syariah menaikan biaya promosi, dana pihak ketiga tetap tidak mengalami kenaikan yang berarti.

Guna menghadapi persaingan yang ketat dengan tetap memperoleh laba yang diinginkan, perbankan dituntut tidak hanya sekedar menguatkan profesionalisme dan perluasan usaha, tetapi harus pula, mengadakan komunikasi dengan para pemakai jasa perbankan, antara lain melalui kegiatan promosi, sehingga dapat memelihara kesehatan usaha dan meningkatkan kepercayaan terhadap usaha perbankan.

\section{Sumber Dana Pihak Ketiga}

Sumber dana ini merupakan sumber dana terpenting bagi kegiatan operasi bank dan merupakan ukuran keberhasilan bank jika mampu membiayai operasinya dari sumber dana ini. Pencarian dana dari sumber ini relatif paling mudah jika dibandingkan dengan sumber lainnya. Mudah dikarenakan asal dapat memberikan bunga yang relatif lebih tinggi dan dapat memberikan fasilitas menarik lainnya seperti hadiah dan pelayanan yang memuaskan menarik dana dari sumber ini tidak terlalu sulit. Kemudian keuntungan lainnya dana yang tersedia di masyarakat tidak terbatas.

${ }^{13}$ Kotler, Philip dan AB Susanto, Manajemen Pemasaran Di Indonesia, Jilid 2 (Jakarta: Salemba Empat, 2001), h.795. 
Kerugiannya adalah sumber dana dari sumber ini relatif lebih mahal jika dibandingkan dari dana sendiri baik untuk biaya bunga maupun biaya promosi.

Untuk memperoleh dana dari masyarakat luas dapat menggunakan tiga macam jenis simpanan (rekening). Masing-masing jenis simpanan memiliki keunggulan tersendiri, sehingga bank harus pandai dalam menyiasati pemilihan sumber dana. Sumber dana yang dimaksud adalah: Simpanan Giro, Simpanan Tabungan dan Simpanan Deposito. ${ }^{14}$

\section{Unsur-unsur Dana Pihak Ketiga}

Sumber dana atau unsur-unsur dana pihak ketiga adalah sebagai berikut:

\section{Simpanan Giro}

Dalam bahasa sehari-hari kata simpanan sering disebut dengan nama rekening atau accoun, di mana artinya sama. Dengan memiliki simpanan atau rekening berarti memiliki sejumlah uang yang disimpan di bank tertentu atau dengan kata lain simpanaa adalah dana yang dipercayakan oleh masyarakat untuk dititipkan di bank. Dana kemudian dikelola oleh bank dalam bentuk simpanan seperti rekening giro, rekening tabungan dan rekening deposito untuk kemudian diusahakan kembali dengan cara disalurkan ke masyarakat.

Pengertian giro menurut undang-undang Perbankan Nomor 10 tahun 1998 tanggal 10 November 1998 adalah ${ }^{15}$ Simpanan yang penarikannya dapat dilakukan setiap saat dengan menggunakan cek, bilyet giro, sarana perintah pembayaran lainnya atau dengan cara pemindahbukuan. Sedangkan giro wadiah adalah ${ }^{16}$ dana nasabah yang dititipkan di bank. Setiap saat nasabah berhak mengambilnya dan berhak mendapatkan bonus dari keuntungan pemanfaatan dana giro oleh bank. Besarnya bonus h. $47-48$.

${ }^{14}$ Kasmir, Manajemen Perbankan (Jakarta: PT.Raja Grafindo Persada, 2007), ed.1-7,

${ }^{15}$ Ibid, h. 50.

${ }^{16}$ Syafi'I Antonio, Bank Syariah: analisa kekuatan, peluang, kelemahan dan ancaman (Yogyakarta: Ekonisia, 2006), h. 19. 
tidak ditetapkan dimuka tetapi benar-benar merupakan "kebijaksanaan" bank, sungguhpun demikian nominalnya diupayakan sedemikian rupa untuk senantiasa kompetitif.

\section{Simpanan Tabungan}

Berbeda dengan simpanan giro, simpanan tabungan memiliki ciri khas tersendiri. Jika simpanan giro digunakan oleh para pengusaha atau para pedagang dalam bertransaksi maka simpanan tabungan digunakan untuk umum dan lebih banyak digunakan oleh perorangan baik pegawai, mahasiswa atau ibu rumah tangga. Kemudian bank dalam menetapkan suku bunga juga berbeda dalam arti rata-rata suku bunga simpanan tabungan lebih tinggi dari jasa giro yang diberikan kepada nasabah. Begitu pula metode perhitungan bunga serta berbagai keuntungan lainnya seperti hadiah atau cindera mata.

Pengertian tabungan menurut Undang-Undang Perbankan nomor 10 tahun 1998 adalah ${ }^{17}$ Simpanan yang penarikannya hanya dapat dilakukan menurut syarat-syarat tertentu yangd isepakati, tetapi tidak dapat ditarik dengan cek, bilyet giro dan atau alat lainnya yang dipersamakan dengan itu. Sedangkan tabungan mudharabah adalah ${ }^{18}$ dana yang disimpan akan dikelola bank untuk memperoleh keuntungan. Keuntungan akan diberikan kepada nasabah berdasarkan kesepakatan bersama.

\section{Simpanan Deposito}

Sumber dana dari masyarakat luas yang ketiga adalah simpanan deposito dan pemilik deposito disebut deposan. Berbeda dengan dua jenis simpanan sebelumnya, di mana simpanan deposito mengandung unsur jangka waktu (jatuh tempo) lebih panjang dan dapat ditarik atau dicairkan setelah jatuh tempo. Begitu juga dengan suku bunga yang relatif lebih tinggi dari kedua jenis simpanan sebelumnya.

Pengertian Deposito menurut Undang-undang No.10 tahun 1998

\footnotetext{
${ }^{17}$ Kasmir, Manajemen Perbankan, h. 57.

${ }^{18}$ Syafi'i, Bank Syariah: analisa kekuatan, peluang, kelemahan dan ancaman,h. 19.
} 
adalah ${ }^{19}$ simpanan yang penarikannya hanya dapat dilakukan pada waktu tertentu berdasarkan perjanjian nasabah penyimpanan dengan bank. Dan Deposito Investasi Mudharabah adalah ${ }^{20}$ dana yang disimpan nasabah hanya bisa ditarik berdasarkan jangka waktu yang telah ditentukan dengan bagi hasil keuntungan berdasarkan kesepakatan bersama.

\section{Pengaruh Biaya Promosi Pada Dana Pihak Ketiga}

Biasanya kegiatan promosi dianggarkan sebagai biaya operasi (current expense) dan secara tersirat menganggap bahwa manfaatnya terpakai habis seketika itu. Joel Dean dan lainnya memajukan bahwa periklanan (dan agaknya juga usaha promosi lain) seharusnya diperlakukan sebagai penanaman modal. Alasan mereka adalah bahwa manfaat dari hasil penanaman ini kerapkali (1) tidak segera tampak dan (2) timbul selama beberapa tahun berturut-turut. ${ }^{21}$

Sementara untuk penentuan penyediaan dana guna usaha promosi terdapat empat cara. Cara ini kerap kali dibahas dalam hubungan dengan penyediaan dana periklanan saja, akan tetapi cara ini memang juga dapat dilakukan dalam hubungan penentuan biaya seluruh kegiatan promosi. ${ }^{22}$ Antara lain:

\section{a) Perbandingan dengan pendapatan dana pihak ketiga.}

Penyediaan dana promosi dapat dihubungkan dengan pendapatan jumlah dana pihak ketiga atas dasar berikut. Pengeluaran ini dapat ditetapkan sebagai persentase dari angka pendapatan masa lalu atau yang akan datang. Sebenarnya metode ini tidak sehat dan secara logis tidak konsisten. Dengan memperkirakan pendapatan yang akan datang dan menetapkan penyediaan dana promosi, maka pimpinan tetap menganggap periklanan dan penjualan personal sebagai hasil pendapatan. Jika pendapatan dana

${ }^{19}$ Kasmir, Manajemen Perbankan, h. 63.

${ }^{20}$ Syafi'i, Bank Syariah: analisa kekuatan, peluang, kelemahan dan ancaman,h. 19.

${ }^{21}$ Kotler, Philip dan AB Susanto, Manajemen Pemasaran Di Indonesia, Jilid 2 (Jakarta: Salemba Empat, 2001), h.152.

${ }^{22}$ William, J Stanton, Prinsip-Prinsip Pemasaran (Jakarta: Erlangga, 1993), h.152. 
pihak ketiga bergantung pada promosi, sebagaimana hal sebenarnya, maka pimpinan tidak dapat meramalkan pendapatan sebelum penyediaan dana promosi tersebut ditetapkan. Hasil yang tidak diinginkan yang lain dari metode penentuan ini adalah bahwa pengeluaran untuk promosi dikurangi jika pendapatan dana pihak ketiga turun. Dan sebenarnya pada saat itulah promosi makin banyak diperlukan.

Metode persentase dari pendapatan dana pihak ketiga dinyatakan memiliki sejumlah keuntungan. Pertama, metode ini berarti pengeluaran promosiakanberubah sesuai "kemampuan" perusahaan. Hal inimemuaskan manajer keuangan, yang menganggap bahwa biaya harus mempunyai hubungan yang erat dengan pergerakan penjualan perusahaan selama siklus bisnis itu. Secara tidak langsung menyiratkan bahwa biaya promosi menjadi salah satu faktor yang dapat mempengaruhi dana pihak ketiga. Kedua, metode ini memaksa manajer untuk berpikir menurut hubungan antara biaya promosi, harga jual, dan laba per unit. Ketiga, mendorong stabilitas kompetitif sampai sejauh perusahaan pesaing menghabiskan persentase yang hampir sama dari pendapatan dana pihak ketiga mereka untuk promosi. ${ }^{23}$

\section{b) Tugas atau sasaran}

Dasar yang lebih sehat untuk menetapkan anggaran promosi adalah menetapkan tugas-tugas apa yang yang harus dilaksanakan dalam program promosi dan kemudian menetapkan berapa biayanya. Berbagai variasi dari metode ini digunakan sekarang. Metode tugas memaksa untuk menggambarkan realistis tujuan program promosi.

Adakalanya pendekatan ini dinamai metode membangun (buildup method) berdasarkan atas bagaimana cara ia bekerja. Umpamanya, sebagai tujuan, perusahaan dapat menetapkan akan mamasuki suatu pasaran geogarafis baru. Para pejabat kemudian menetapkan bahwa usaha ini memerlukan tambahan 10 tenaga penjualan, gaji dan biaya tenaga ini akan berjumlah Rp. 270 juta setahun. Gaji pengawas penjualan tambahan dan biaya tambahan untuk keperluan kantor dan tata usaha akan berjumlah

\footnotetext{
${ }^{23}$ Kotler, Manajemen Pemasaran Di Indonesia, h. 794-795.
} 
Rp. 35 juta. Jadi, dalam bidang penjualan personal pada promotional mix dana tambahan sebesar Rp. 305 juta perlu disediakan. Perkiraan-perkiraan serupa dapat diadakan mengenai rancangan biaya periklanan, promosi penjualan dan cara-cara promosi lain yang akan digunakan. Maka, penyediaan dana promosi dibangun dengan menjumlah biaya tugas-tugas promosi satu persatu, yang diperlukan untuk melaksanakan tujuan mamasuki daerah pemasaran baru. ${ }^{24}$

\section{c) Penggunaan semua dana yang tersedia.}

Perusahaan baru kerapkali memasukkan seluruh dana yang tersedia ke dalam program promosi. Sasaran disini adalah membangun pendapatan selama 1 hingga 5 tahun pertama. Setelah masa itu, pimpinan mengharapkan memperoleh laba dan lebih mampu menyusun anggaran promosi dengan cara lain.

\section{d) Mengikuti jejak pesaing}

Cara lemah untuk menetapkan anggaran promosi, yaitu suatu cara yang tersebar cukup luas sehingga pantas untuk diajukan di sini, ialah cara mengikuti jejak pesaing dalam menetapkan anggaran promosi. Metode ini lemah dalam dua segi. Pertama, pesaing dapat saja sama-sama tidak mengikuti cara menyusun anggaran promosi secara tepat. Kedua, tujuan dan strategi promosi perusahaan dapat berbeda sekali dengan keadaan pesaing, disebabkan karena perbedaaan perencanaan strategi pemasaran perusahaan. ${ }^{25}$

Tujuan akhir dari beberapa promosi adalah untuk mendapatkan seseorang untuk membeli suatu produk maupun jasa atau dalam kasus organisasi nirlaba untuk mengambil beberapa tindakan (misalnya, donor darah). Pemasar dapat mencari respons kognitif, afektif, atau perilaku audiens sasaran, yaitu, pemasar dapat memasuki sesuatu ke dalam pikiran konsumen, mengubah sikap konsumen, atau membuat konsumen bertindak. ${ }^{26}$

\footnotetext{
${ }^{24}$ William, Prinsip-Prinsip Pemasaran, h. 153.

${ }^{25}$ Ibid

${ }^{26}$ Kotler, Manajemen Pemasaran Di Indonesia, h. 781.
} 
Penjualanpun dapat dianggarkan dengan menganilisis produk, wilayah, pelanggan dan tentu saja pola musiman perkiraan penjualan. Anggaran harus dikompilasi oleh manajer penjualan. Ia akan meminta pendapat para wiraniaga dan menggunakan teknik peramalan statistik dalam riset pasar. ${ }^{27}$

Mengingat manajemen penjualan merupakan fungsi (sering yang terpenting) dalam strategi pemasaran, penting sekali bagi seorang manajer penjualan untuk sedikit menyadari taktik pemasaran lainnya sehingga ia dapat berkontribusi dan mengambil manfaat dari berbagai taktik itu. ${ }^{28}$ Dalam hal ini salah satunya adalah bagian promosi. Manajer penjualan harus mengintegrasikan kegiatannya dengan upaya pemasaran yang lainnya, dengan demikian biaya pemasaran dimanfaatkan semaksimum mungkin sehingga akan menghasilkan pendapatan dana pihak ketiga yang maksimum pula.

\section{Pelaksanaan Promosi Pada PT.Bank Syari'ah Mega Indonesia}

Dalam tingkat persaingan yang semakin tajam di antara sesama lembaga keuangan dan semakin kompleksnya masalah-masalah yang timbul dalam kegiatan pemasaran suatu produk, maka dituntut adanya ketelitian dalam memilih beberapa alternatif yang tepat agar dapat menyesuaikan diri dengan permintaan dan perubahan pasar. Adapun pokok-pokok yang harus dipertimbangkan dalam menentukan bentuk-bentuk promosinya yaitu:

1. Nasabah yang dituju

Sebelum menentukan bentuk promosi, bank melihat produk apa yang ditawarkan kepada nasabah dan sasaran apa yang akan dituju. Kemudian dari kedua unsur tersebut dapat dilihat segmen mana yang akan dituju.

2. Jumlah nasabah yang hendak dicapai

Sebelum pemilihan bentuk promosi, bank melakukan survey lapangan dengan maksud untuk mengetahui bentuk dan media apa yang paling tepat untuk digunakan saat ini. Apabila jumlah nasabah yang ingin dicapai prefectif massal, maka personal selling kurang tepat

${ }^{27}$ Dennis lock, Nigel Farrow, Manajemen Umum, (Jakarta: PT.Elek Media Komputido, 1989), buku 1, h. 133.

${ }^{28}$ Ibid, h. 316. 
untuk digunakan. Sebaiknya advertising publisitas sangat tepat untuk diterapkan dengan menempatkan iklan pada majalah atau surat kabar tertentu.

3. Anggaran untuk promosi

Dalam pemilihan dan menggunakan bentuk maupun media promosi harus seefisien dan seefektif mungkin, untuk itu harus ditentukan terlebih dahulu sebagai bentuk maupun media yang akan digunakan sesuai dengan dana yang tersedia sehingga dapat mencapai sasaran yang telah ditetapkan. Dalam kaitannya dengan pemasaran, perusaahaan harus dapat memilih cara promosi yang paling tepat dalam melaksanakan kegiatan promosinya, dalam hal ini efektif dalam pengumpulan dana. Dalam hal ini bank Mega Syariah melakukan promosi melalui saluran komunikasi, baik sarana manusia maupun sarana bukan manusia dengan sasaran antara lain:

a. Untuk merangkul nasabah baru yang belum pernah berhubungan dengannya.

b. Merangkul kembali nasabah yang selama ini tidak aktif lagi membeli produk.

c. Berusaha menjaring para nasabah yang pernah berhubungan dengan bank-bank lain.

d. Menjerat nasabah yang suka berpindah-pindah dan dampaknya tidak loyal lagi dengan bank-bank yang selama ini dijalin oleh nasabah tersebut.

e. Meningkatkan jumlah nasabah, berarti meningkatkan volume penjualan kepada pemakai yang sudah menjadi nasabah suatu bank.

Dalam pemikiran kegiatan promosi ada beberapa cara yang dapat ditempuh oleh perusahaan untuk mengingkatkan penjualan, yaitu:

\section{Periklanan (advertising)}

Iklan merupakan segala bentuk pesan tentang suatu produk yang disampaikan lewat media, ditujukan kepada sebagian atau seluruh masyarakat. ${ }^{29}$

${ }^{29}$ Direktorat Bina Pers dan Grafika Departemen Penerangan RI, "Tata Krama dan Tata Cara perikalan Indonesia" (Jakarta: 1993), h.45. 
Iklan merupakan bagian dari strategi pemasaran yang bertujuan untuk memberitahukan serta memberi petunjuk serta kepada pembeli potensial dan untuk meningkatkan omset penjualan. Jadi periklanan merupakan kegiatan untuk memperkenalkan produk guna memikat keinginan konsumen agar memiliki barang yang diiklankan.

Banyak media yang dipergunakan untuk mengiklankan produk dari Bank Mega Syariah antara lain:

\section{a. Surat Kabar}

Surat kabar dinilai oleh Bank Mega Syariah sebagai media yang cukup baik karena dapat mencakup lapisan pembaca yang luas dan segala lapisan masyarakat sesuai dengan target marketnya, sehingga memberikan kesempatan kepada para pembaca baik di pasaran local maupun nasional. Masyarakat dapat melihat keadaan ataupun peristiwa sehari-hari di halaman surat kabar, oleh karena itu iklan Bank dapat diletakkan di halaman olah raga atau kolom-kolom berita ekonomi yang biasanya banyak menarik minat para pembaca untuk membacanya.

Surat kabar tersebut memuat informasi dalam bentuk tulisan atau lebih mengenai laporan keuangan dan sistem operasional bank serta komentar para ahli ekonomi tentang perbankan syariah yang tujuannya untuk menumbuhkan kepercayaan masyarakat untuk menyimpan dananya di Bank Mega Syariah. Adapun media yang digunakan atau surat kabar yang dipilih adalah Republika, Kompas, Pelita, Bisnis Indonesia, Media Indonesia, Sinar pagi, Berita Buana, Suara Pembaharuan, Suara Merdeka, dll.

b. Majalah

Salah satu keunggulan majalah adalah kualitas visual yang sangat prima karena umumnya dicetak diatas kertas berkualitas tinggi. Sehingga memiliki daya tarik yang lebih dan terkesan enak untuk dibaca yang bertujuan menarik minat konsumen. Majalah juga dapat dibaca berulang-ulang, tidak langsung dibuang. Bank Mega Syariah memilih majalah yang sudah dikenal oleh masyarakat seperti Info Bank, Gatra, Sabili, Tempo, modal, dll.

Bank Mega Syariah juga mengeluarkan majalah yang biasa terbit 
satu bulan sekali, yang menyajikan berbagai produk baru yang muncul, majalah ini biasanya diberikan kepada karyawan dan nasabah secara gratis.

c. Media Elektronik

\section{1) Melalui Radio}

Radio merupakan salah satu alat media pengiklanan yang sifatnya sebagai pemberitahuan dan mengingatkan atas iklan yang telah dimuat di televisi, majalah, Koran dsb. Dan radio merupakan media yang fleksibel dan media yang memilki sifat instrusif yaitu orang akan terekspos oleh iklan pada saat iklan tersebut disiarkan dan iklan tersebut hadir di tengah-tengah siaran tanpa mengakibatkan orang beralih kesiaran lain. Sifat instrutif ini menyebabkan radio memiki efektivitas untuk memutuskan perhatian konsumen dan menciptakan minat. Hal ini yang menyebabkan radio cocok digunakan untuk pengenalan produk baru.

Penggunaan media ini sangat berbeda dengan media cetak, karena dengan radio orang buta huruf dan orang yang tidak sempat membaca koran atau majalah dapat mengerti pesan yang disampaikan. Dengan media ini dapat dicapai para pendengar di rumah, mobil, tempattempat pekerjaan dan dimanapun mereka berada. Berita peristiwa yang disiarkan oleh radio pada umumnya lebih cepat dari yang lain.

\section{2) Melalui Televisi}

Penggunaan media televisi ini sangat efektif sekali karena dapat dilihat sampai ke pelosok desa. Iklan media televisi memberikan pelayanan yang sangat baik sekali. Ditunjukkan kepada para nelayan dan petani yang oleh Bank Mega Syariah yang memang menitikberatkan pada pelayan koperasi maupun masyarakat kecil, menengah, dan atas. Dan PT.Bank Syariah Mega Indonesia (Bank Mega Syariah) bekerja sama dengan PT.Televisi Transformasi (TRANS TV) dan TRANS 7.

\section{3) Internet}

PT.Bank Mega Syariah Indonesia (Bank Mega Syariah) memilki Homepage: http://www.megasyariah.co.id. Yang bersifat publication untuk seluruh masyarakat yang ingin mengetahui lebih jauh BMS, di mana di dalamnya terdapat informasi tentang Bank Mega Syariah, 
Sekilas Bank Mega Syariah, Visi Misi dan Nilai-nilai, Struktur Organisasi, Dewan komisaris, Dewan Pengawas Syariah, Dewan Direksi, Pemegang Saham, Penghargaan, Produk layanan (Produk pendanaan,produk pembiayaan dan jasa layanan), cabang ATM (Kantor Cabang dan Jaringan ATM), Simulasi (Simulasi Pembiayaan, table NISBAH, Kurs Valas), Berita, Laporan Keuangan (Ikhtisar Keuangan dan Neraca).

\section{4) Outdoor}

Media ini meliputi penggunaan neon signyang ditempatkan pada jalurjalur yang ramai, dilewati lalu lintas ataupun tempat keramaian seperti, pertokoan, shelter bus, dan tempat strategis lainnya. Pemasangan dilaksanakan selama satu tahun yang kemudian dapat diperpanjang atau pindah ke tempat lain pada periode promosi berikutnya.

\section{5) Brosur}

Bank Mega Syariah menggunakan brosur dalam memperkenalkan pelayanan jasa yang ditawarkan dan mengenai ketentuan umum yang mudah dimengerti dan dipahami. Brosur ini dibuat sedemikian rupa agar dapat mempunyai daya tarik tersendiri seperti dibuat dengan tata warna, desain, kata-kata dan desain grafis yang baik agar memberikan eksekutif dan menarik minat nasabah untuk membacanya dan biasanya ditempatkan pada tempat-tempat yang dapat terlihat dengan mudah oleh orang atau nasabah pada waktu nasabah datang untuk suatu keperluan di Bank Mega Syariah. Bank Mega Syariah juga menyediakan brosur tersebut di meja front office masing-masing cabang atau kantor kas dan di setiap kegiatan yang diadakan diikuti oleh Bank Mega Syariah. Adapun keputusan-keputusan yang diambil dalam periklanan adalah mengenai:

a) Besarnya anggaran periklanan

b) Cara prosentasi

c) Media yang dipakai

d) Jadwal pemasanagn iklan

Pelaksanaan promosi melalui periklanan yang dilaksanakan Bank Mega Syariah mempunyai keunggulan antara lain:

1) Bila dilihat dari medianya, seperti majalah dan surat kabar, maka 
periklanan di sini mempunyai keuntungan yaitu dapat mencapai target market yang telah ditetapkan oleh Bank Mega Syariah.

2) Sedangkan bila dilihat dari isinya, maka iklan tersebut mempunyai keuntungan yaitu dapat mengkomunikasikan benefit uatau keuntungan produk yang ditawarkan kepada calon nasabah (konsumen). Adapun kekurangannya adalah: biaya yang dikeluarkan oleh Bank Mega Syariah cukup besar.

Adapun strategi periklanan yang dijalankan oleh Bank Mega Syariah adalah menggunakan keberadaan media massa dengan seoptimal mungkin.

\section{Personal Selling}

Penjualan Personal yaitu interaksi langsung antar satu atau lebih calon pembeli dengan tujuan melakukan penjualan. ${ }^{30}$

Adapun cara yang ditempuh oleh Bank Mega Syariah adalah

a. Kunjungan ke suatu forum untuk melakukan seminar atau pelatihan yang bertujuan memperkenalkan dan menawarkan produk Bank Mega Syariah.

b. Kunjungan kepada nasabah yang potensial dan menawarkan produkproduk BMS yaitu nasabah yang memiliki usaha dengan prospek yang cerah.

c. Kontak langsung dengan nasabah, yaitu melalui petugas bank dengan nasabah yang langsung datang ke Bank, nasabah berhak untuk mendapatkan informasi dan penerangan tentang produk bank yang dihasilkan dan keunggulannya. Kegiatan ini cukup efektif karena adanya komunikasi dua arah, nasabah datang langsung bertanya dengan petugas tentang apa saja yang berkaitan dengan produk tersebut.

Personal selling dilakukan oleh Bank Mega Syariah sifatnya tidak terus menerus, dimana pihak Bank Mega Syariah melakukan promosi ini hanya ditujukan kepada koperasi kecil dan menengah, juga diberikan

${ }^{30}$ Kotler, Philip dan AB Susanto, Manajemen Pemasaran Di Indonesia, Jilid 2 (Jakarta: Salemba Empat, 2001), h. 800. 
kepada pengusaha kecil, menengah dan atas. Biasanya pengusaha kecil ini diberikan penyuluhan-penyuluhan, karena biasanya sebagai petani dan nelayan pedesaan. Jadi dana yang ditetapkan tidak terlalu besar.

\section{Promosi Penjualan}

Strategi yang dikeluarkan oleh Bank Mega Syariah dalam melaksanakan promosi penjualan adalah dengan cara memberikan kemudahankemudahan serta kelebihan-kelebihan dari pelayanan atau service kepada nasabahnya. Karena yang dilayani disini menyangkut untuk kepentingan orang banyak, koperasi dan rakyat kecil. Selain itu Bank Mega Syariah juga memberikan hadiah-hadiah berupa kalender, buku, agenda, pena dan lain-lain yang diberikan kepada nasabah yang setia kepada Bank Mega Syariah, dan juga diberikan kepada calon nasabah baru.

Adapun keuntungan yang didapat dari promosi ini yaitu biaya yang digunakan relatif rendah, karena pihak Bank Mega Syariah lebih mengutamakan atas pelayanan atau service yang diberikan kepada konsumen. Sedangkan kekurangannya yaitu adanya keterbatasan jumlah konsumen yang mendapat pelayanan tentang informasi dari Bank Mega Syariah.

\section{Publisitas}

Pada saat publisitas, perusahaan harus mengeluarkan sejumlah biaya walaupun memang tidak banyak, karena biasanya publisitas ini diwujudkan dalam bentuk berita dengan maksud untuk menambah perhatian simpatisan, kepercayaan masyarakat terhadap keputusan dan kebijaksanaan dari perusahaan. Dalam dunia perbankan, publisitas sering lebih disebut dengan humas dan sarana yang dipakai dalam berbagai sistem masyarakat. Di sini apabila masyarakat merasa mendapatkan pelayanan yang kurang baik, maka publisitas akan bersifat negatif. Oleh karena itu, pimpinan beserta seluruh karyawan Bank Mega Syariah sedapat mungkin memberikan pelayanan sebaik-baiknya sehingga nantinya akan diperoleh publisitas perusahaan yang baik yang akan dinilai oleh nasabah itu sendiri.

Promosi melalui humas yang dilakukan Bank Mega Syariah yaitu dengan membuat ulasan-ulasan, lembaran tulisan dan makalah yang dipulbikasikan yang terlibat dalam seminar-seminar atau pelatihan yang 
sering diselenggarakan oleh suatu pihak yang tujuannya untuk memberikan informasi seputar bank Syariah semisal sistem operasional dan kegiatan usaha. Seperti yang baru saja dilakukan oleh PT.Bank Syariah Mega Indonesia (Mega Syariah Cabang Kuningan) telah melakukan pelatihan atau pun kerjasama dengan Universitas Islam Negeri Syarif Hidayatullah Jakarta pada tanggal 11-12 Juni 2008 di Fakultas Syariah dan hukum.

Keuntungan yang didapat dari publisitas ini adalah:

a. Biaya yang digunakan relatif rendah.

b. Dapat mencakup tentang promosi produk baru maupun informasi tentang kebijaksanaan yang dilakukan oleh Bank Mega Syariah.

Sedangkan kekurangannya adalah dari tanggapan masyarakat bisa negatif apabila publisitas disampaikan dengan tidak baik.

Dengan melihat kelebihan-kelebihan dan kekurangannya yang terdapat dalam masing-masing elemen promosi tersebut dia atas, maka dapat dikatakan bahwa promosi yang menguntungkan bagi perusahaan dilihat dari kekurangan dan keuntungan masing-masing dari promosi perusahaan dapat mencapai target market yang telah ditetapkan.

Hal ini sangat beralasan karena pada periklanan selain kita dapat memperkenalkan produk yang diatawarkan, kita dapat menyampaikan segala keuntungan yang didapat bila calon nasabah atau konsumen memiliki produk tersebut, sehingga konsumen tertarik untuk produk yang dikeluarkan.

\section{Penerapan Promosi Dalam Perspektif Islam Pada PT. Bank Syariah Mega Indonesia (Bank Mega Syariah)}

Islam adalah agama yang bersifat komprehensif dan universal. Komprehensif artinya mengatur seluruh aspek kehidupan manusia, yang secara garis besar dapat diklasifikasikan menjadi 3 sub sistem yaitu aqidah, syariah, dan akhlak. Aqidah adalah hukum-hukum yang bersangkut paut dengan keimanan, dan ketauhidan yang merupakan dasar keimanan seorang muslim. Syariah adalah hukum-hukum yang mengatur hubungan manusia dengan kholik maupun manusia dengan makhluk. Sedangkan akhlak menitik beratkan pada pendidikan rohani dan pembersihan hati dari sifat-sifat tercela dan menghiasi dengan sifat-sifat yang terpuji. Wahyu Allah yang tertuang $\mathrm{Al}$ - 
Qur'an dan As-Sunah mencakup semua fenomena kehidupan. Dasar-dasar, aturan-aturan, serta semua hukum yang berkaitan dengan aqidah, ibadah dan muamalah. Syariah islamiyah dan seluruh hukumnya tidak boleh dipisahpisahkan atau dipecah-pecah, karena bersifat kully. Mengambil sebagian dan meninggalkan sebagian yang lain tidak akan mencapai objekyif syariah tujuan dan falsafahnya tidak akan dapat ditegakkan. ${ }^{31}$

\section{Deskripsi Besaran Biaya Promosi dan Dana Pihak Ketiga di PT.Bank Syariah Mega Indonesia}

Promosi merupakan cara penyampaian pesan-pesan yang dapat mempengaruhi konsumen agar berubah sikapnya dengan tujuan permintaan dan penjualan. Sebagai gambaran untuk pengeluaran biaya pertahun akan ditampilkan dalam hasil olah data yang dilakukan dengan menggunakan SPSS for windows versi 15.0 mengenai jumlah besaran biaya promosi yang digunakan dengan dana tertentu dan jumlah dana pihak ketiga yang dapat dikumpulkan.

Meskipun dana yang alokasikan untuk promosi ini terus mengalami peningkatan dari tahun ke tahun, namun hal itu lakukan oleh PT.Bank Syariah Mega Indonesia guna menunjukkan keberadaan bank kepada masyarakat luas merupakan salah satu bank yang berkompeten dan patut diperhitungkan oleh masyarakat luas dalam memilih sebuah bank syariah.

Promosi harus dilakukan secara benar demi mencapai tujuan yang telah direncanakan. Jika promosi yang dilakukan tidak tepat maka hal itu hanya mengeluarkan beban biaya yang tidak mendatangkan hasil yang tidak optimal, untuk itu maka penerapannya harus benar-benar direncanakan, dilakukan dan dikelola sedemikian rupa guna mencapai sasaran yang diharapkan.

Data-data yang diperlukan dalam analisis ini didapat dari laporan neraca dan laporan laba rugi triwulan PT.Bank Syariah Mega Indonesia, yang dimulai dari tahun 2004-2008. dengan demikian diharapkan dapat diketahui perkembangan laporan keuangan tiap bulannya. Dari hasil olah data yang dilakukan dengan menggunakan SPSS for windows versi 15.0

${ }^{31}$ Shamsul, Falah, "Makalah Etika Bisnis Islam” (Jakarta: 2004), h.4. 
dapat dijelaskan mengenai variabel-variabel yang terdapat pada model regresi linear sederhana dan korelasinya dapat dilihat pada tabel-tabel di bawah ini:

\section{Besaran biaya promosi di PT.Bank Syariah Mega Indonesia}

Yang dimaksud besaran biaya promosi di PT.Bank Syariah Mega Indonesia adalah jumlah besaran biaya untuk kegiatan promosi yang dikeluarkan oleh divisi promosi di tiap periodenya (per triwulan). Jumlah besaran biaya promosi diberikan secara umum dari Desember 2004 sampai Juni 2008 mengalami kenaikan saldo tahunan sebesar Rp. 1.236.000.000 menjadi sebesar Rp. 1.697.000.000 atau selisih kenaikan Rp. 461.000.000. sebagimana tercermin dalam tabel 4.1 dibawah ini:

Tabel 4.1. Data Besaran Biaya Promosi (dalam jutaan rupiah)

\begin{tabular}{|l|l|l|}
\hline Tahun & \multicolumn{1}{|c|}{ Triwulan } & Besaran Biaya Promosi \\
\hline 2004 & Desember (1) & 1236 \\
\hline \multirow{3}{*}{2005} & Maret (2) & 163 \\
& Juni (3) & 430 \\
& September (4) & 709 \\
& Desember (5) & 1544 \\
\hline \multirow{3}{*}{2006} & Maret (6) & 210 \\
& Juni (7) & 515 \\
& September (8) & 1071 \\
& Desember (9) & 2340 \\
\hline \multirow{2}{*}{2007} & Maret (10) & 696 \\
& Juni (11) & 1533 \\
& September (12) & 2110 \\
& Desember (13) & 3933 \\
\hline \multirow{2}{*}{2008} & Maret (14) & 525 \\
& Juni & 1697 \\
\hline
\end{tabular}




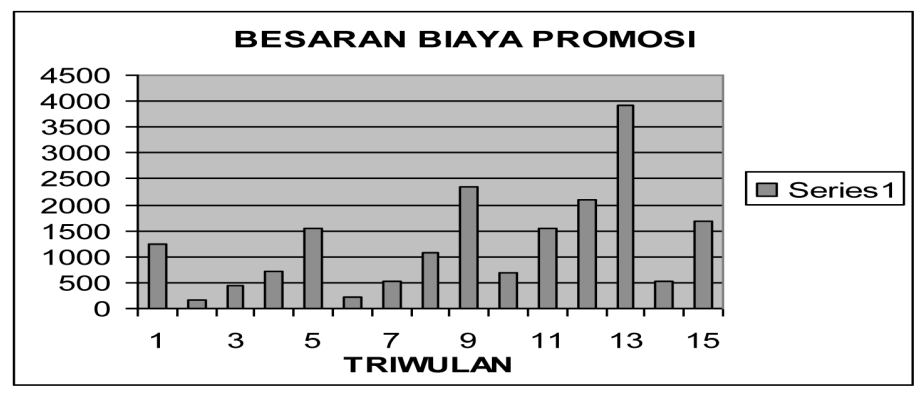

Gambar 2. Besaran Biaya Promosi

Jumlah besaran biaya promosi PT.Bank Syariah Mega Indonesia tiap tahunnya mengalami kenaikan dan penurunan jumlah besaran biaya promosi terkecil pada periode bulan Maret tahun 2005 atau triwulan ke-2 sebesar Rp.163.000.000 dan jumlah besaran biaya promosi terbesar pada periode bulan Desember tahun 2007 atau pada triwulan ke-13 yakni sebesar Rp.3.933.000.000

Tabel 4.2. Perhitungan rata-rata, dan varians besaran biaya promosi Descriptive Statistics

\begin{tabular}{|c|c|c|c|c|c|}
\hline & $\mathrm{N}$ & Minimum & Maximum & Mean & Std. Deviation \\
\hline BP & 15 & 163,00 & 3933,00 & 1247,4667 & 1004,47853 \\
\hline Valid N (listwise) & 15 & & & & \\
\hline
\end{tabular}

Sumber: data olahan SPSS 15.0

Tabel 4.2 menunjukkan bahwa varian X (besaran biaya promosi), memiliki nilai rata-rata (mean) sebesar Rp.1247,4667, standar deviasi sebesar 1004.47 dan jumlah data sebanyak 15 data.

\section{Jumlah Dana Pihak Ketiga PT.Bank Syariah Mega Indonesia}

Yang dimaksud dengan jumlah dana pihak ketiga PT.Bank Syariah Mega Indonesia terdiri atas tabungan, giro dan deposito yang tertera pada laporan keuangan. Dana pihak ketiga secara umum dari Desember 2004 sampai Juni 2008 mengalami kenaikan sebesar Rp. 274.875.000.000 menjadi sebesar Rp. 1.877.502.000.000 pada juni 2008, atau selisih kenaikan Rp. 1.602.627.000.000 
Tabel 4.3. Data Jumlah Dana Pihak Ketiga (dalam jutaan rupiah)

\begin{tabular}{|l|l|l|}
\hline Tahun & \multicolumn{1}{|c|}{ Triwulan } & \multicolumn{1}{|c|}{ Jumlah Dana Pihak Ketiga } \\
\hline 2004 & Desember (1) & 274875 \\
\hline \multirow{2}{*}{2005} & Maret (2) & 301056 \\
& Juni (3) & 297939 \\
& September (4) & 413126 \\
& Desember (5) & 825154 \\
\hline \multirow{2}{*}{2006} & Maret (6) & 696819 \\
& Juni (7) & 1039434 \\
& September (8) & 1567154 \\
& Desember (9) & 2159539 \\
\hline \multirow{2}{*}{2007} & Maret (10) & 2318519 \\
& Juni (11) & 2060055 \\
& September (12) & 2107725 \\
& Desember (13) & 2168531 \\
\hline \multirow{2}{*}{2008} & Maret (14) & 1801940 \\
& Juni (15) & 1877502 \\
\hline
\end{tabular}

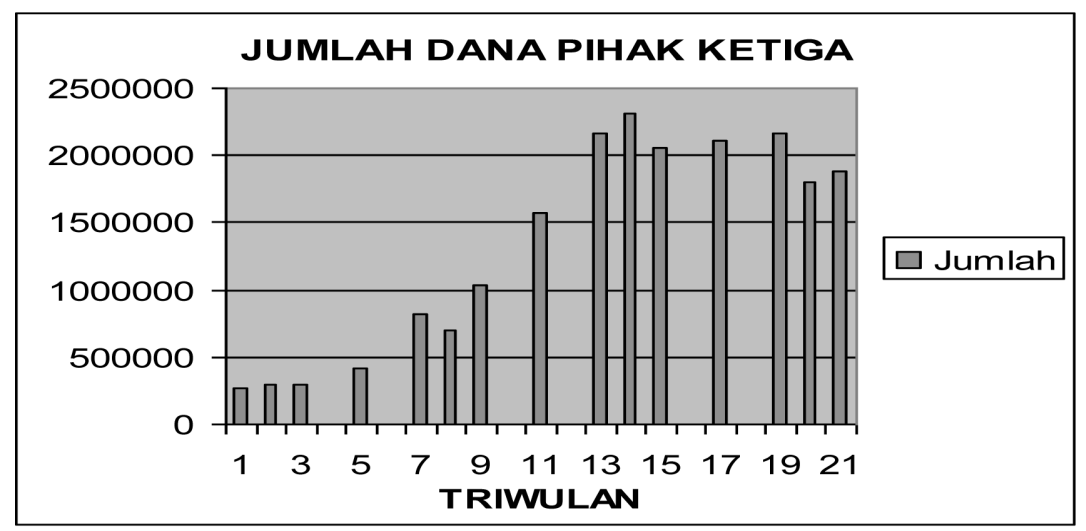

Gambar 3. Jumlah Dana Pihak ketiga

Jumlah dana pihak ketiga PT.Bank Syariah Mega Indonesia tiap tahunnya cenderung mengalami kenaikan dan penurunan, jumlah dana pihak ketiga terkecil pada periode awal yakni bulan Desember tahun 
2004 atau triwulan pertama sebesar Rp.274.875.000.000 dan jumlah dana pihak ketiga terbesar pada periode bulan Desember tahun 2007 atau pada triwulan ke-14 yakni sebesar Rp.1.877.502.000.000.

Tabel 4.4. Perhitungan rata-rata dan deviasi Jumlah Dana Pihak Ketiga Descriptive Statistics

\begin{tabular}{|l|c|c|c|c|c|}
\hline & N & Minimum & Maximum & Mean & Std. Deviation \\
\hline $\begin{array}{l}\text { DPK } \\
\text { Valid N } \\
\text { (listwise) }\end{array}$ & 15 & 274875,00 & 2318519,00 & 1327291,2000 & 797448,24575 \\
\hline
\end{tabular}

Sumber: Data olahan SPSS 15.0

Tabel 4.4 menunjukkan bahwa variable X (Jumlah Dana Pihak ketiga) memilki nilai rata-rata (mean) sebesar Rp.1327291.2, standar deviasi sebesar 797448.24 dan jumlah data sebanyak 15 data.

\section{Analisa Kuantitatif Statistik dan Interpretasi Data.}

Analisis regresi dan korelasi disebut juga Leas Square Analysis. Tujuannya adalah untuk melihat pengaruh dan hubungan antar variabel. ${ }^{32}$ Penulis mencoba mengkombinasikan dua cara penghitungan untuk mencari hasil regresi dan koefisien korelasi, yaitu menggunkan SPSS 15.0 dan menggunakan rumus uji t, uji f dan uji koefisien determinasi untuk korelasi. Hal ini dilakukan untuk mendapatkan hasil yang valid.

\section{Pengujian Hipotesis}

\section{Analisis Regresi}

Untuk persamaan regresi:

$\mathrm{Y}=\mathrm{a}+\mathrm{bX}$

Dimana: $\mathrm{X}=$ variabel independen yaitu Besaran biaya promosi

$\mathrm{Y}=$ variabel dependen yaitu jumlah DPK

$\mathrm{a}=$ konstanta

${ }^{32}$ Freddy Rangkuti, Marketing Analysis Made Easy: Teknik Analisis Pemasaran dan Analisis Kasus Menggunakan Exel dan SPSS, (Jakarta: PT.Gramedia Pustaka Utama, 2005), h.37. 
$\mathrm{b}=$ koefisien regresi

a) Koefisien regresi

Dari table 4.5 dapat diketahui bahwa nilai variabel X (besaran biaya promosi) terhadap variable Y (jumlah dana pihak ketiga) sebesar 2,2 \%. Angka ini lebih kecil dari taraf signifikan 5\% $(0,05)$. Dari data ini maka dapat ditarik kesimpulan bahwa biaya promosi berpengaruh secara signifikan terhadap jumlah dana pihak ketiga. Berdasarkan hasil pengolahan SPSS versi 15.0 didapat $\mathrm{Y}=272,302+0,001 \mathrm{X}$, memiliki arti bahwa jika biaya promosi 0 maka dana pihak ketiga 272,302 , dan bila biaya promosi $1 \%$ maka dana pihak ketiga $0,1 \%$.

Tabel 4.5

Coefficients(a)

\begin{tabular}{|l|l|l|l|l|l|}
\hline \multirow{2}{*}{ Model } & \multicolumn{2}{|c|}{$\begin{array}{c}\text { Unstandardized } \\
\text { Coefficients }\end{array}$} & $\begin{array}{l}\text { Standardized } \\
\text { Coefficients }\end{array}$ & \multicolumn{1}{|c|}{$\mathbf{t}$} & \multicolumn{1}{c|}{ Sig. } \\
\cline { 2 - 7 } & B & Std. Error & Beta & B & $\begin{array}{l}\text { Std. } \\
\text { Error }\end{array}$ \\
\hline \multirow{2}{*}{1 (Constant) } & 272.302 & 435.498 & & .625 & .543 \\
\cline { 2 - 7 } BP & .001 & .000 & .583 & 2.589 & .022 \\
\hline
\end{tabular}

a Dependent Variable: DPK

b) Uji t

Dimana berdasarkan hasil pengolahan SPSS versi 15.0 untuk konstanta didapat nilai $\mathrm{t}$ sebesar 2,589 dan t tabel sebesar 1,771. Karena nilai dari $\mathrm{t}_{\text {hitung }}(2,589)>\mathrm{t}_{\text {tabel }}(1,771)$, maka secara individu variabel $\mathrm{X}$ (besaran biaya promosi) mempunyai pengaruh yang signifikan terhadap variabel $Y$ (jumlah dana pihak ketiga).

c) Uji F

Selanjutnya dilakukan uji $\mathrm{F}$ yang bertujuan untuk melihat seberapa besar pengaruh variabel independen secara bersama-sama mempengaruhi variabel dependen. Berdasarkan pengolahan data menggunakan SPSS versi 15 (tabel 4.6) didapatkan hasil nilai $F$ sebesar 6,703, kemudian diperbandingkan dengan nilai $\mathrm{F}$ tabel sebesar 4,67 , atau $\mathrm{f}_{\text {hitung }}(6,703)>\mathrm{f}$ 
tabel $(4,67)$ sehingga dapat disimpulkan bahwa uji $\mathrm{F}$ adalah signifikan yang berarti bahwa secara bersama-sama variabel independen (besaran biaya promosi) mempengaruhi variabel dependen (jumlah dana pihak ketiga).

Tabel 4.6

ANOVA(b)

\begin{tabular}{|l|c|c|c|c|c|}
\hline \multicolumn{1}{|c|}{ Model } & $\begin{array}{c}\text { Sum of } \\
\text { Squares }\end{array}$ & Df & $\begin{array}{c}\text { Mean } \\
\text { Square }\end{array}$ & F & Sig. \\
\hline 1 & 4805701.137 & 1 & 4805701.137 & 6.703 & $.022(\mathrm{a})$ \\
\cline { 2 - 6 } $\begin{array}{l}\text { Regression } \\
\text { Residual } \\
\text { Total }\end{array}$ & 9319978.596 & 13 & 716921.430 & & \\
\cline { 2 - 6 } & 14125679.733 & 14 & & & \\
\hline
\end{tabular}

a Predictors: (Constant), Y

b Dependent Variable: $\mathrm{X}$

d) Uji Koefisien Determinasi

Kemudian dilihat besaran koefisien determinasi $\left(\mathrm{R}^{2}\right)$, berdasarkan tabel 4.7 didapat nilai R Square sebesar $0,583^{2}=0,34 \times 100 \%=34 \%$. Hal ini berarti bahwa jumlah dana pihak ketiga dipengaruhi oleh besaran biaya promosi sebesar 34\% dan sisanya 66\% dipengaruhi oleh variabel lain selain besaran biaya promosi. Seperti: pelayanan kepada nasabah, hadiah dan bonus, seminar, kurs, dll.

Tabel 4.7

Model Summary

\begin{tabular}{|c|c|c|c|c|}
\hline Model & $\mathrm{R}$ & R Square & $\begin{array}{c}\text { Adjusted } \\
\text { R Square }\end{array}$ & $\begin{array}{c}\text { Std. Error of the } \\
\text { Estimate }\end{array}$ \\
\hline 1 & $.583(\mathrm{a})$ & .340 & .289 & 846.712 \\
\hline
\end{tabular}

a Predictors: (Constant), Y

\section{Analisis Korelasi}

Korelasi yang didapat yaitu sebesar 0,583 termasuk ke dalam korelasi sempurna positif dan merupakan korelasi yang kuat antara variabel besaran biaya promosi dengan variabel jumlah dana pihak ketiga. 
Adapun statistik parameternya adalah sebagai berikut:

Ho = tidak terdapat hubungan positif antara variabel besaran biaya promosi dengan jumlah dana pihak ketiga

$\mathrm{H}_{1} \quad=$ terdapat hubungan positif antara variabel besaran biaya promosi dengan dana pihak ketiga

Berdasarkan hasil perhitungan statistik dengan mengkorelasikan X (besaran biaya promosi) dan Y (jumlah DPK) maka diperoleh hasil sebagai berikut:

Tabel 4.8

Correlations

\begin{tabular}{|l|l|r|r|}
\hline & & X & \multicolumn{1}{|c|}{ Y } \\
\hline BP & Pearson Correlation & 1 & $.583(*)$ \\
\hline & Sig. (2-tailed) & & .022 \\
\hline & N & 15 & 15 \\
\hline DPK & Pearson Correlation & $.583(*)$ & 1 \\
\hline & Sig. (2-tailed) & .022 & 15 \\
\hline & N & 15 & 15 \\
\hline
\end{tabular}

* Correlation is significant at the 0.05 level (2-tailed).

a) Uji t

untuk hasil t hitung:

$t=\frac{0.583 \sqrt{15-2}}{\sqrt{1-0,583^{2}}}$

$t=\frac{2,1020}{0 ., 8124}=2,587$

Dengan derajat kebebasan $15-2=12$, dengan tingkat kepercayaan $5 \%$ didapat $\mathrm{t}$ tabel sebesar 1,782 . Karena $\mathrm{t}$ hitung $(2,587)>$ daripada $\mathrm{t}$ tabel $(1,771)$, maka Ho ditolak dan $\mathrm{H}_{1}$ diterima yang berarti terdapat hubungan positif antara variabel besaran biaya promosi dengan jumlah dana pihak ketiga.

b) Uji Koefisien Determinasi

Untuk koefisien determinasi dilakukan penghitungan dengan rumus 


$$
\begin{aligned}
& R^{2}=r^{2} \times 100 \% \\
& R^{2}=(0,583)^{2} \times 100 \%=33,89 \%
\end{aligned}
$$

Untuk keperluan interpretasi hasil perhitungan dari koefisien korelasi sebesar 0,583 hubungan yang sedang atau cukup kuat. Berdasarkan hasil tersebut maka diketahui bahwa variabel X (besaran biaya promosi) memberikan pengaruh sebesar 33,89\% terhadap jumlah dana pihak ketiga dan sisanya $66,11 \%$ dipengaruhi oleh faktor lain di luar besaran biaya promosi, seperti; pelayanan kepada nasabah, hadiah atau bonus, seminar, kurs, dll

\section{Analisis Hasil Empiris dan Interpretasi data}

Dalam tingkat persaingan yang semakin tajam di antara sesama lembaga keuangan dan semakin kompleksnya masalah-masalah yang timbul dalam kegiatan pemasaran suatu produk, maka dituntut adanya ketelitian dalam memilih beberapa alternatif yang tepat agar dapat menyesuaikan diri dengan permintaan dan perubahan pasar. Adapun pokok-pokok yang sudah dijalankan oleh Bank Mega Syariah dalam menentukan bentukbentuk promosinya.

Dalam Anggaran untuk promosi, hal ini Bank Mega Syariah melakukan promosi melalui saluran komunikasi, baik sarana manusia maupun sarana bukan manusia.

Adapun strategi periklanan yang dijalankan oleh Bank Mega Syariah adalah menggunakan keberadaan media massa dengan seoptimal mungkin. Personal selling yang dilakukan oleh Bank Mega Syariah sifatnya tidak kontinyu, dimana pihak Bank Mega Syariah melakukan promosi ini hanya ditujukan kepada koperasi kecil dan menengah, juga diberikan kepada pengusaha kecil, menengah dan atas. Biasanya pengusaha kecil ini diberikan penyuluhan-penyuluhan, karena biasanya sebagai petani dan nelayan pedesaan. Jadi dana yang ditetapkan tidak terlalu besar. Strategi yang dikeluarkan oleh Bank Mega Syariah dalam melaksanakan promosi penjualan adalah dengan cara memberikan kemudahan-kemudahan serta kelebihan-kelebihan dari pelayanan atau service kepada nasabahnya, Selain itu Bank Mega Syariah juga memberikan hadiah-hadiah berupa kalender, buku, agenda, pena dan lain-lain yang diberikan kepada nasabah 
yang setia kepada Bank Mega Syariah, dan juga diberikan kepada calon nasabah baru. Promosi melalui humas yang dilakukan Bank Mega Syariah yaitu dengan membuat ulasan-ulasan, lembaran tulisan dan makalah yang terlibat dalam seminar-seminar atau pelatihan yang sering diselenggarakan oleh suatu pihak yang tujuannya untuk memberikan informasi seputar bank Syariah semisal sistem operasional dan kegiatan usaha.

Berdasarkan hasil empiris di atas terlihat bahwa terdapat adanya pengaruh dan hubungan yang positif dan kuat antara besaran biaya promosi dengan jumlah dana pihak ketiga. Sehingga hipotesis ini dapat diterima dan terbukti.

Dapat diinterpretasikan bahwa salah satu faktor yang berpengaruh terhadap peningkatan jumlah dana pihak ketiga Bank Mega Syariah adalah Jumlah besaran biaya promosi. Dalam penelitian ini dapat dilihat bahwa besar dan kecilnya jumlah besaran biaya promosi dapat mempengaruhi jumlah dana pihak ketiga.

\section{Penutup}

Berdasarkan hasil analisis dan pembahasan yang telah dikemukakan pada bab sebelumnya, maka dapat diberikan suatu kesimpulan sebagai berikut:

Pertama, Jumlah besaran biaya promosi yang dikeluarkan PT.Bank Syariah Mega Indonesia untuk keperluan promosinya cenderung mengalami kenaikan dan penurunan di tiap periodenya. kenaikan pada tahun 2006 periode akhir Desember dikarenakan oleh adanya peningkatan promosi penjualan dan hubungan masyarakat (publisitas). Peningkatan besaran biaya promosi di tahun 2007 periode akhir Desember sebesar 3933 juta merupakan peningkatan terbesar selama periode yang diteliti. Karena perusahaan mencanangkan strategi penghimpunan dana pihak ke tiga retaik dan murah yang dijaring dari tabungan dan giro. Dimana PT.Bank Syariah Mega Indonesia (Bank Mega Syariah) melakukan kerjasama membuka unit pelayanan syariah (UPS) seperti: Galery BMS di Bank Mega, UPS BSM di Bank Mandiri, dan UPS Bank Muamalat di kantor Pos.

Kenaikan mencolok di tahun 2008 akhir periode Juni sebesar 1697 antara lain dikarenakan oleh gencarnya kegiatan promosi yang dilakukan perusahaan pada tahun itu yang meliputi pemasangan iklan di media 
cetak, media elektronik dan media ruang. Disamping itu pada periode ini perusahaan juga melakukan kegiatan promosi penjualan publisitas untuk jenis produk tabungan wadiah, deposito mudharabah dan giro wadiah seperti: tabungan wadiah (Mega Tama), deposito mudharabah (Mega Syariah Depo), dan giro wadiah, agar para calon nasabah mengenal dan tertarik pada produk yang dikeluarkan Bank Mega Syariah.

Kedua, Hasil Uji Regresi dan Korelasi. Diketahui bahwa hasil perhitungan regresi dilihat dari nilai probabililitas variable $\mathrm{X}$ (besaran biaya promosi) terhadap variabel Y (jumlah dana pihak ketiga) sebesar 2,2 \%. Angka ini lebih kecil dari taraf signifikan 5\% $(0,05)$. Dari data ini maka dapat ditarik kesimpulan bahwa biaya promosi berpengaruh secara signifikan terhadap jumlah dana pihak ketiga. Karena nilai dari $t_{\text {hitung }}(2,589)>\mathrm{t}$ tabel $(1,960)$, maka secara individu variabel $\mathrm{X}$ (besaran biaya promosi) mempunyai pengaruh yang signifikan terhadap variabel Y (jumlah dana pihak ketiga). Dengan nilai $\mathrm{F}$ tabel sebesar 4,67, atau $\mathrm{f}_{\text {hitung }}(6,703)>$ $\mathrm{f}_{\text {tabel }}(4,67)$ sehingga dapat disimpulkan bahwa uji $\mathrm{F}$ adalah signifikan yang berarti bahwa secara bersama-sama variabel independen (besaran biaya promosi) mempengaruhi variabel dependen (jumlah dana pihak ketiga). Didapat nilai R Square sebesar 0,5832 $=0,34$ X 100\% $=34 \%$. Hal ini berarti bahwa jumlah dana pihak ketiga dipengaruhi oleh besaran biaya promosi sebesar $34 \%$ dan sisanya $66 \%$ dipengaruhi oleh variabel lain selain pelayanan biaya promosi.

Korelasi yang didapat yaitu sebesar 0,583 termasuk ke dalam korelasi sempurna positif dan merupakan korelasi yang kuat antara variabel besaran biaya promosi dengan variabel jumlah dana pihak ketiga. Karena t hitung $(2,587)>$ daripada $\mathrm{t}_{\text {tabel }}(1,771)$, maka Ho ditolak dan $\mathrm{H}_{1}$ diterima yang berarti terdapat hubungan positif antara variabel besaran biaya promosi dengan jumlah dana pihak ketiga. Untuk keperluan interpretasi hasil perhitungan dari koefisien korelasi sebesar 0,583 hubungan yang sedang atau cukup kuat. Berdasarkan hasil tersebut maka diketahui bahwa variabel X (besaran biaya promosi) memberikan pengaruh sebesar 33,89\% terhadap jumlah dana pihak ketiga dan sisanya $66,11 \%$ dipengaruhi oleh faktor lain di luar pelayanan biaya promosi. 


\section{Pustaka Acuan}

Al-Qur'anul Karim

Alma, Buchari, Manajemen Pemasaran dan Pemasaran Jasa. Bandung: Alfabeta, 2007.

Antonio, Syafi'I, Bank Syariah: Analisa Kekuatan, Peluang, Kelemahan dan Ancaman, Yogyakarta: Ekonisia, 2006.

Assauri, Sofjan, Manajemen Pemasaran. Jakarta: PT.Raja Grafindo Persada, 2004.

Dennis lock, Nigel Farrow, Manajemen Umum, Jakarta: PT.Elek Media Komputido, 1989, buku 1

Direktorat Bina Pers dan Grafika Departemen Penerangan RI, Tata Krama dan Tata Cara perikalan Indonesia, 1993, Jakarta.

Eferin, Sujoko, dkk, Merode Penelitian Untuk Akuntansi, Sebuah Pendekatan Praktis, Malang: Bayu Media Publishing, Juni, 2004, cet-1.

Fajriah, Siti, "10 Pilar Pengembangan Bank Syari'ah”. Artikel diakses pada tanggal 11 Januari 2008 dari situs http://kasei- unri.org/index. php?option $=$ com .

Faizi, "Bank Syariah Entaskan Kemiskinan". Artikel diakses pada tanggal 11 Januari 2008 dari situs http://www.RepublikaOnline.co.id

Kasmir, Manajemen Perbankan, Jakarta: PT.Raja Grafindo Persada, 2007, ed.1-7.

, Pemasaran Bank. Jakarta: Kencana, 2005

Kotler, Philip dan AB Susanto, Manajemen Pemasaran Di Indonesia, Jilid II, Salemba Empat, Jakarta, 2001.

, Prinsip-Prinsip Pemasaran. Jakarta: Erlangga, 2004.

Kertajaya, Hermwan dan Muhammad Syakir Sula, Syari'ah Marketing, Bandung: PT.Mizan Pustaka, 2006, Cet.3.

Keegan, Warren J, Manajemen Pemasaran. Global Warren J. Keegan; alih bahasa, Alexander Sindoro ; penyunting, Bob Widyahartono. Jakarta: Prenhallindo, 1996.

Lupiyoadi, Rambat, Manajemen Pemasaran Jasa: Teori dan Praktik. Jakarta: PT.Salemba Emban Patria, 2001.

Nasution, MA, dan Thomas, Buku Penuntun Membuat Tesis Skripsi Disertasi 
Makalah. Jakarta: PT.Bumi Aksara, 2006.

Rangkuti,Fredy, Marketing Analysis Made Easy: Teknik Analisis Pemasaran dan Analisis Kasus Menggunakan Exel dan SPSS, Jakarta: PT.Gramedia Pustaka Utama, 2005.

Santoso, Singgih, Buku Latihan SPSS Statistik Parametrik,Jakarta: PT.Elex Media Koputindo, 2000.

Saladin, Djaslim. H, Dasar-Dasar Manajemen Pemasaran. Intisari dari buku William J.Stanton-Michael J. Etzel-Bruce J. Walker Edisi ke IX Tahun 1991. Bandung: Mandar Maju, 1994.

Simorangkir.O.P, Pengantar Pemasaran Bank. Jakarta: Aksara Persada Indonesia, 1991

Sinungan. M, Tekhnik Manajemen Bank yang Praktis. Jakarta: Bumi Aksara, 1991.

Soetantini, Noer, "Gerakan Menabung Syariah Genjot Akselerasi Industri Perbankan Syariah". Artikel diakses pada tanggal 11 Januari 2008 dari situs http://kasei-unri.org/index.php?option=com.

Shamsul, Falah, "Makalah Etika Bisnis Islam”, Jakarta, 2004.

Sumarni, Murti, Manajemen Pemasaran Bank. Yogyakarta: Liberty, 2002.

Sugiyono, Metode Penelitian Bisnis. Bandung: CV. Alfabeta, 2007.

Swastha, Basu, Azas-Azas Marketing. Yogyakarta: Liberty, 2002.

Tim Penyusun, Pedoman Penulisan Skripsi, Penerbit UIN Jakarta Press, cetakan tahun 2007.

Umar, Husein, Metode Penelitian Untuk Skripsi dan Tesis Bisnis. Jakarta: PT. RajaGrafindo Persada, 2004

Wicaksono, Beni, "Pemilihan Media Dalam Strategi Promosi Yang Optimal Untuk Meningkatkan Volume Penjualan". artikel diakases pada tanggal 11 januari 2008 dari situs http://www.Republikaonline.co.id William, J Stanton, Prinsip-Prinsip Pemasaran. Jakarta: Erlangga, 1993. www.megasyariah.co.id.

Yusuf, Burhanuddin, "Mengelola Promosi Pemasaran". Makalah Kuliah Formal Jurusan Muamalah, Jakarta: Fakultas Syariah dan Hukum, 2003.

Yusuf, Qardawi, Peran Nilai dan Moral dalam Perekonomian Islam, Jakarta: Rabbani Press, 1997, Cet. 1. 